\title{
Kehittämisehdotusten arviointia
}




\title{
Aikuiskoulutusneuvoston testamentti -
}

\author{
Hallinnollista ideologiaa kansalaisten arjesta
}

\begin{abstract}
Aikuiskoulutusneuvoston $\quad 16.12$. 1987 julkaisema muistio aikuiskoulutuksen kehittämisestä 1988-1990 antaa voimakkaan vaikutelman siitä, miten hallinnon ja politiikan oma ideologinen diskurssi kulkee ratkaisevasti erillään kansalaisten ja erilaisten opetusja sivistysyhteisöjen elämästä. Neuvostojen ideologiset paperit panevat lukijansa tulkintataidon koetukselle yhä uudelleen.
\end{abstract}

Neuvoston muistio alkaa aikuiskoulutuksen merkityksen korostamisella ja toteamuksella, että valtion tulo- ja menoarviossa ei tätä huomioida vuonna 1988 eikä budjetin kehitysnäkymissä v:een 1992 mennessä. Korkeasti pätevöitynyt neuvosto ei ole siis saanut eduskuntaa vakuutetuksi niistä kansainvälisen kilpailun, teknologisen kehityksen, työelämän ja ammattien muutoksen sekä työllisyyden hoitamisen koko aikuiskoulutusjärjestelmälle aiheuttamista suurista haasteista, joista se itse kirjoittaa? Ehkä neuvosto on mieltänyt itsensä puhtaaksi asiantuntijaelimeksi, joka jättäytyy varsinaisen politiikanteon ulkopuolelle tekemään kompromisseja? Siinä tapauksessa neuvostoa on kuitenkin kritisoitava siitä, että se on laiminlyönyt oman asemansa erittelyn eikä ole paneutunut kysymykseen, miksi aikuiskoulutuksesta ei ole avattu laajaa poliittista debattia.

Mistä johtuu, että aikuiskoulutuksen merkityksestä vallitsee konsensus, mutta siihen liittyy saamattomuutta konkreettisissa teoissa? Siinteleekö hallinnollisten suunnittelijoiden ja päättäjien mielessä yhä vielä sellainen SUURI JÄRJESTELMÄ, jonka kustannusten ajatteleminenkin huimaa?

Sama keskitettyyn hallintoon sitoutuminen, joka tuo mukanaan suunnittelun vaihtoehdottomuuden ja on vaivannut aikuiskoulutuksen hallinnollista kehittämistyötä 1980-luvun ajan, jatkuu tässäkin muistiossa. Se jarruttaa ilmeisesti jokaisen suunnitteluelimen toimintaa, koska jokaisessa pää- töksessä on tehtävä se yksi ainoa valinta, jonka jokainen taho voi hyväksyä ja tulkita omaksi voitokseen. Epäkonkreetit periaatteet ovat konsensuksen kannalta parhaita. Sillä voidaan peittää näkyvistä sekin, että neuvostossa ei osata lausua uutta kysymystä, millaista sivistystä tarvitaan:

Uudet haasteet vaativat neuvoston mielestä, että on välttämättä kehitettävä ensi vuosikymmenen tarpeita varten aikuisten ammatillinen perus- ja lisäkoulutusjärjestelmä ja sen tukena toimiva yleissivistävän koulutuksen tarjontajärjestelmä. Vanha jako kummittelee, vaikka neuvostolla ei olisikaan mitään konkreettista noihin laatikoihin asettaa.

Yleissivistävään aikuiskoulutukseen neuvosto tuntuu muutoin olevan tyytyväinen, paitsi kaipaa sitä, että aikuiskoulutukselle "tulisi nyt löytää myös laadullisesti ja sisällöllisesti uutta ilmettä. Tämä on sitäkin tärkeämpää, kun lyhytjänteisyys ja pintakulttuurin vetovoima lisääntyvät yhteiskunnassa.'

"Uusi ilme" tulee kyllä toteutumaankin: kun valtiovarainministeriö on päättänyt, ettei aikuiskoulutukseen osoiteta enempää resursseja, uusi strategia tulee olemaan koulutuksen enenevä kaupallistaminen (tässä muistiossa siitä käytetään nimeä maksullisen palvelun periaate), tutkintojen markkinointi ihmisille yhä uusin, vaihtuvin keinoin. Näin koulutus joutuu tosissaan kilpailemaan "ilmeellään". Ja entistä tärkeämmäksi nousee kysymys, kenellä on varaa koulutukseen.

Tulevaisuuden kannalta filosofia saattaa olla ilmettä tärkeämpi. Aineksia olisi uuteen keskusteluun sivistyksestä - myös näiden suunnittelevien neuvostojen sisällä. Uuden aikuiskoulutusneuvoston toivoisin työnsä aluksi lukevan muistion At overskride graenser, jonka Tanskan kansansivistyksen ja aikuisopetuksen kehittämiskeskus on julkaissut 1986.

Hallinnon "uudistamiseksi" neuvosto esittää $\mathrm{mm}$. periaatteen, että "aikuiskoulutushallinnon on mahdollistettava aikuiskoulutuksen kokonaissuunnittelu, mutta toisaalta yksittäisten asioiden ratkaisuvalta on vietävä mahdollisimman lähelle niitä, joita asiat koskevat". Termi "yksittäiset asiat" voidaan tulkita miten tahansa. Samaten "niihin, joita asiat koskevat", voidaan lukea hyvin erilaisia tahoja aina sen mukaan, missä mielessä asioiden oletetaan niitä koskevan. "Mahdollisimman lähelle" ei vielä määrittele päättäjiä. Kannattaa verrata Tanskan aikuisopetuksen ja kansansivistyksen 10 kohdan ohjelman ensimmäiseen periaatteeseen: "Aikuisopetusta ja kansansivistystä kehitetään hajautetun mallin mukaan, missä osanottajille, opettajille ja aloitteentekijöille annetaan laaja vapaus päättää sisällöstä ja muodosta. Julkinen valta varmistaa aikuisväestölle laajan opetustarjonnan yhtä lailla vapaan sivistystyön kuin tutkintotavoitteisen yleissivistävän ja ammatillisen opetuksen alueella sekä antaa taloudellista tukea aikuisten osallistumiselle niihin." Lukija saa tästä tietää, kuka päättää ja mistä päätetään.

Aikuiskoulutusneuvoston paperi sisältää myös hyviä toiveita ja ne on aika mukavasti ryhmitelty. Kauneusvirheinä ovat sitten hurskaat toiveet, kuten henkilöstökoulutuksen kohdentaminen vanhempiin ikäluokkiin, jotta nämä pysyisivät paremmin mukana työelämässä.

Kun luemme ja kuulemme toistuvasti, miten ihmisiä rationalisoidaan työelämästä ulos, tämänkin ideologisen muistion arvo rapistuu. Yhteiskunnallinen lisääntyvä eriarvoisuus ohitetaan lopultakin näissä suunnittelevissa neuvostoissa - koostuvathan ne keskenään varsin tasaveroisista asiantuntijoista. 